\title{
Canadian drug firms boost R\&D spending
}

\section{Ottawa}

CANADA's patent drug manufacturers, buoyed by the federal government's endorsement last month of an international trade proposal that extends patent protection for pharmaceuticals, have announced new research and development investments that will total Can $\$ 309$ million over the next four years.

The government's move was a reward to the industry for more than doubling its R\&D expenditures since 1987, the last time that patent protection was extended. It also is meant to prod the industry to continue that trend. "These measures will encourage increased R\&D in Canada, providing high-paying, skilled jobs for the medical and scientific communities," asserted Michael Wilson, international trade minister, in announcing the government's support for the GATT proposal.

The trade proposal is part of the current Uruguay Round of the General Agreement on Tariffs and Trade (GATT), announced last December in Geneva. It is designed to set common standards on international property protection for 108 member countries. The drug patent portion of the agreement was aimed particularly at Canada, which among indus"compulsory licensing" for pharmaceuticals. This system allows generic drug companies to copy and market brandname products almost immediately after development and testing by the innovator, provided they pay a fixed royalty fee for the duration of the patent. Such licences are almost always granted.

The system was intended to hold down drug prices through increased competition. But the effect was to give patent drug manufacturers here a shorter period of market exclusivity for their products than is found elsewhere, and thus to reduce their profits. Many such Canadian companies are subsidiaries of multinationals.

To deal with this problem, Canada passed a bill in 1987 that extended market exclusivity for drugs from 7 to 10 years. In return, the drug industry promised to increase research expenditures. Although this improved the innovators' competitive situation within the country, they were trialized countries has a unique system of

still less well-off than those in the US, for example, with 14 years of exclusivity, and the Europeans, with 15 years.

The GATT proposal would abolish compulsory licensing, although all licenses issued before the December draft was proposed would continue to apply. In practice, Canadian companies would receive exclusivity for three years more than at present, and the proposal would not directly affect other industrial countries. At the same time, it would force drug manufacturers from developing countries to adopt similar patent protection, but only after a grace period of up to 10 years.

In return for the extension granted in 1987, Canadian patent drug companies pledged to increase over the next decade their research spending from 4.9 per cent of sales to 10 per cent. A 1991 study by the independent agency set up by the federal government to monitor their progress, the Patented Medicines Prices Review Board, shows that they had already almost reached that goal: In 1990 R\&D spending was 9.2 per cent of sales, and the Pharmaceutical Manufacturers Association of Canada reported last October that its members were spending 10.1 per cent of sales.

The 1987 patent law change also created jobs. An association survey last July showed that the number of research jobs had grown by 48 per cent, from 925 to 1,327 , in three years. Overall, the industry added 1,386 jobs between 1987 and 1990 .

The industry has also kept its promise to keep drug prices reasonable. The government's monitoring board found that existing patented drug prices stayed below the country's consumer price index between 1987 and 1990, as well as below the guidelines set by the government.

David Spurgeon by 1997 , he wants the EC to spend an extra 3,500 million ECU a year (about $\$ 4,400$ million) on research and training to increase economic competitiveness.

Officials in the EC member states are still waiting for a breakdown of Delors' spending plans. But the proposed 3,500 million ECU increase is expected to include more than 2,000 million ECU for research and development, doubling the EC's present annual spending on its Framework research programme. Several of the member states, in particular Britain, will balk at this figure, and as Britain retained its effective veto over increases in EC research spending at December's EC summit meeting in Maastricht (see Nature 355, 3; 2 January 1992), Delors' budget is unlikely to be accepted in full.

"Europe's competitive edge has been blunted," said Delors in explaining the need for his proposal. "Its research potential is being eroded." As a remedy, the Commission wants the EC to support more 'near market' industrial research - projects aimed at specific industrial sectors and leading to marketable products. That approach is championed by Filippo charge of research.

France and Italy are likely to support these plans. But the idea is expected to be criticized by Britain, with backing from Germany and the Netherlands. They argue that EC support for industrial research should be restricted to 'precompetitive' projects, designed to develop underlying new technologies.

The outcome of this debate may well depend on the result of the British general election, expected in April this year. Glyn Ford, leader of the British Labour Members of the European Parliament, expects that his party would be more receptive to Delors' plans for near-market research projects if Labour were to replace the current Conservative government. Ford, formerly a science policy researcher at the University of Manchester, believes the EC should not be restricted to 'precompetitive' research programmes.

"Our problem in Europe is competing with the United States and Japan in high technology," he says. Ford argues that the Japanese government spends a larger amount on near-market research than does the EC, despite its protestations to the contrary. "We need to look at what they do, rather than what they say they do," he says.
Peter Aldhous
UK FUND CREATED

\section{HIV compensation}

\section{London}

IN a sharp reversal of previous policy, the UK Department of Health announced on Monday of this week (17 February) that it is setting aside $£ 12$ million to compensate some 80 non-haemophiliacs who were infected with HIV by blood transfusions carried out in the mid-1980s under the National Health Service (NHS).

The government had previously refused to extend the compensation that has already been offered to the 1,200 British haemophiliacs who contracted HIV from transfused blood products. It argued that this would set a dangerous precedent for compensating people harmed by NHS treatment, where negligence could not be proved. Infected people with dependent children can expect to receive up to $£ 80,500$ in compensation. 